\title{
Faith and fandom: young Indonesian Muslims negotiating K-pop and Islam
}

\author{
Teguh Wijaya Mulya ${ }^{1}$
}

Accepted: 12 September 2021

(ᄋ) The Author(s), under exclusive licence to Springer Nature B.V. 2021

\begin{abstract}
Contemporary scholars in the intersecting field of popular culture and Islamic studies have argued for the importance of researching the ways Muslims engage with, make meaning of, and (re)produce different forms of popular culture. The current study continues these endeavours by examining a hitherto understudied form of popular culture in this field, namely, Korean popular culture. As previous studies on Islam and popular culture have drawn attention to, the focus of this study is on how this specific form of popular culture has been in/compatible with Islamic values, beliefs, and practices. Taking Indonesia as a context, the current study asked: What are the various ways Indonesian Muslim fans negotiate their identities as a Muslim and a K-pop fan? Drawing upon interview data with Indonesian Muslim K-pop fans and publicly available literature such as media reports, news, and websites, the findings exhibited at least four subject positions (available to be) taken up by Muslim K-pop fans, namely, (1) complete opposition, (2) partial opposition, (3) irrelevance, and (4) the interlacing of religious and fan subjectivity. The first two positions are predicated upon a belief that Islam and K-pop culture are in tensions, while the latter two consider there is no tension between one's identity as a Muslim and a K-pop fan. This article contributes to the existing knowledge in the field of Islam and popular culture by offering a nuanced discussion on various possible forms of Muslim K-pop fans' subjectivity.
\end{abstract}

Keywords K-pop · Islam · Religious subjectivity $\cdot$ Fan identity $\cdot$ Indonesia

\section{Introduction}

Contemporary scholars in the intersecting field of popular culture and Islamic studies have argued for the importance of researching the ways Muslims engage with, make meaning of, and (re)produce different forms of popular culture. Popular

Teguh Wijaya Mulya

teguh@staff.ubaya.ac.id

1 Faculty of Psychology, the University of Surabaya, Rungkut, Surabaya, East Java, Indonesia 
culture refers to "expressive practices of everyday life" (Nieuwkerk et al., 2016, p. 10) which are generally "mass mediated, commercialised, pleasure-filled, humourous, and representative of large segments of society" (Weintraub, 2011a, p. i), such as music, movies, television, magazines, comics, fashion, and online (sub)cultures. Getting less attention compared to the so-called "high-culture" such as calligraphy, Arabic music, or Islamic recitation (LeVine, 2008), popular culture may provide a window into the everyday life of the Muslim worlds, where meanings are discursively contested and social imaginations are represented. As Nieuwkerk, LeVine, and Stokes (2016, p. 17) put it, it is in the "repetitiousness and ubiquity", in the capacity to "enliven the bodies", and in the ability to "provoke laughter, dance, new fashion and hairstyles, song, empathy, tears, jokes, stories, dreams", that popular culture becomes a powerful site for ideological struggles by continuously contesting what it means to be(come) a Muslim in the modern society. Taking up this call, the current study joins these scholars to expand academic knowledge on the intersecting field of popular culture and Islam, and seeks to further represent the complexity of contemporary Muslim lives.

One of the major themes in the studies of Islam and popular culture is how various forms of popular culture have been in/compatible with Islamic values, beliefs, and practices. Historically, many theologians of all religions have expressed concerns over and imposed various degrees of restriction on engagement with popular cultures (Otterbeck \& Ackfeldt, 2012). Since the Divine is understood as sacred, eternal, priceless, and in sharp contrast with popular culture which was considered fleeting, human-made, cheap, and worldly (Weintraub, 2011a), popular culture, therefore, was seen as leading people away from religion and morality. In Islam more specifically, some forbidding views positioned popular culture as al-malāh $\bar{\imath}$ or the diversions that indulge Muslims in worldly pleasures and distract them from religious devotion and obligations (Otterbeck \& Ackfeldt, 2012). The entertaining nature of popular culture was also often associated with sexuality, dance, and women's bodies which were common sites of Islamic moral concerns (Weintraub, 2011a). Nevertheless, previous studies have demonstrated how Islamic traditions over the generations were not only co-exist, but also blended with both traditional and modern forms of popular culture in complex and intricate ways. Some examples include heavy metal rock music (LeVine, 2008), punk (sub)cultures (Fiscella, 2012), nasyid music in Malaysia (Barendregt, 2012), dangdut music and dance in Indonesia (Weintraub, 2011b), gamelan and shadow puppets in Java (Sumarsam, 2011), and meuseukat in Aceh (Kartomi, 2011). Destabilising the monolithic, reductive, and Arab-oriented views of Islam, these international studies exhibit the dynamic and contested nature - both contextually and temporally - of the interplay between Islam and popular culture.

The current study contributes to these scholarship of Islam and popular culture by examining a hitherto understudied form of popular culture in this field, namely, Korean popular (K-pop) culture. Since entering the global market in the 2000s, K-pop industry has continuously grown into a major player in the international music industry with an estimation of USD 5 billion annual sales revenue (Bruner, 2020). A popular K-pop boy band, BTS, for example, has topped iTunes chart in 90 countries within 2 days of the release of its new album in November 2020 (BTS' 
New Album, 2020). Despite the (initial impression of) "huge cultural and value gap between Islamic beliefs and global K-pop contents" (Yoon, 2019, p. 3), at least four Muslim-majority countries are among K-pop's top 20 markets, including Indonesia, Malaysia, Turkey, and Saudi Arabia (Hilton, 2020). Currently, there is still a dearth of socio-religious studies on Islam and K-pop culture. Among the limited number of existing studies on K-pop and Islam, researchers have focused on the business (Masood \& Rahim, 2020), cultural (Jung \& Shim, 2014; Malik, 2019), and consumer behaviour aspects of K-pop (Jeong et al., 2017; Jung, 2011) in Muslimmajority countries such as Egypt, Indonesia, Malaysia, and Qatar. In the field of socio-religious studies, four relevant edited collections on the intersection of Islam and popular culture did not touch K-pop culture at all, including anthologies by Harnish and Rasmussen (2011), Weintraub (2011a), Hamamsy and Soliman (2013), and Nieuwkerk, LeVine, and Stokes (2016). To date, there is no research article on K-pop published in Contemporary Islam journal. Therefore, the current study seeks to begin filling this gap by examining the religious subjectivity of Muslim K-pop fans in one of the largest Muslim-majority K-pop market, namely, Indonesia.

Specifically, the research questions in this article are: What are the various ways Indonesian Muslim fans negotiate their identities as a Muslim and a K-pop fan? What subject positions as a Muslim fan are available within the contemporary Indonesian religious landscape they inhabit? In what ways may K-pop culture become a site for contemporary debates on Islam, morality, and popular culture? Through these questions, the current study joins the wider academic endeavours to investigate the interplay between religion, popular culture and the constitution of ostensibly conflicting modern identities in contemporary Indonesia (e.g., Wallach, 2008). The answers to these questions - to some extent - may resonate with the findings in studies on Muslims' engagement with other modern popular cultures; nevertheless, there are specific features of K-pop culture which are more pronounced as compared to them, such as the intense fandom engagement (more in the Findings section). The current study aims to begin illuminating this contextual interplay between Islam and $\mathrm{K}$-pop culture in the ways Indonesian Muslim fans make meaning out of their experience. As religious meaning-making does not exist in historical and social vacuum, the next section will briefly introduce Indonesian contemporary contexts vis-à-vis Islam and popular culture.

Theoretically, this study was built upon the legacy of British cultural studies theorists (e.g., Richard Hoggart, Raymond Williams, and Stuart Hall) who (re)connect texts and other cultural products with society and the individuals producing/ consuming them (Turner, 2003). Texts are understood as permeated with cultural meanings, discourses, and even ideologies. Culture, including popular culture, is considered as a site of ideological struggle where power relations are reconfigured. Here, an individual's sense of self is not seen as essentialist, but conceptualised as "subjectivity" which is continuously constituted through multiple and shifting sociopolitical-cultural discourses in a given context. As further argued by the later generation of British cultural studies scholars (John Storey, Dick Hebdige), the current study considered fans' consumption of K-pop as production of culture (meanings, pleasures, etc.) in which K-pop is not just a commodity, but becomes a part of the fans' cultural identity, personal history, feelings, and memories (Storey, 1999). Such 
production of K-pop fan culture is political in the ways it represents symbolic forms of resistance or, as Hebdige $(1979$, p. 18, 127) puts it, an "oblique gesture of refusal" which challenges "the principle of unity and cohesion", interrupts "the process of normalisation", and contradicts "the myth of consensus" about - in the contexts of this study - being a Muslim and a fan.

\section{A brief contextual introduction: Islam and popular culture in contemporary Indonesia}

Indonesia, the world's fourth most populous country and the home for the world's largest Muslim population, have increasingly become a significant market for K-pop in recent years. With more than 850 thousand K-pop fan clubs (Oh, 2017), Indonesia is the place for one of the biggest and strongest K-pop fandoms in Asia and the world (Yoon, 2019). The relatively wide acceptance of K-pop among Indonesian young fans could be attributed - to a degree - to Indonesia's long history of co-existing, even mutually constitutive, Islam and popular culture; particularly among the traditionally dominant Islamic groups such as Nahdlatul Ulama (NU) and Muhammadiyah. As argued by Weintraub (2011a, p. 3), Islam in Indonesia for many centuries has been characterised as "moderate Islam", where "flexible interpretations of major religious and legal sources regarding scripture, law, gender, and democracy that respond to the contemporary needs of Muslims ... map(s) well onto popular culture as both are widespread, participatory, dialogic, and tolerant of diversity ...". The term "seni Islam" or Islamic art (Harnish and Rasmussen 2011), for example, expresses the hybrid fuse of Islam and local popular culture - albeit not without contestations - such as in the ways Javanese shadow puppet incorporate Sufi themes (Sumarsam, 2011), Acehnese meuseukat female dance performing religious texts (Kartomi, 2011), and the use of dangdut music for da'wa (Irama, 2011).

Indonesia's post-1998 democratic era witnessed the rise of Islamic conservatism, which inevitably contested the long history of moderate stances on popular culture such as those of traditionalist NU and Muhammadiyah. As militaristic and social repressions on conservative and Islamist groups were lifted, expansions of conservative Islamic aspirations were increasingly perceptible in various social domains, from the growth of Islamist-leaning political parties and civil society organisations (e.g., Justice and Prosperity Party, Hizbut Tahrir Indonesia), public expressions of religiosity (particularly the hijab), to Islamic-oriented economy such as halal certification and sharia banking (Fealy, 2019). One of the significant milestones, in terms of Islam and popular culture, was the passing of anti-pornography bill proposed by conservative fractions of the parliament in 2008 which criminalises not only all forms of printed and online sexually explicit materials, but also bodily movements and gestures deemed as suggestive of sexual conduct and eroticism (Undang-undang, 2008). The high-profile case leading to this legislation was a fatwa issued by the conservative MUI (Council of Islamic Ulama) against Inul Daratista, a popular dangdut singer, whose dancing, clothes, and stage performance were deemed pornographic and, therefore, incompatible with Islamic morality (Weintraub, 2011a). It is within these socio-politico-religious discursive landscape 
of contemporary Indonesia characterised by tensions between the traditionally moderate groups and the rising new conservatives that young Muslims cultivate their sense of identity, including - for some - the identity as a Muslim and a K-pop fan. In the next section, I will discuss contemporary academic knowledge on this specific intersection of Islam, K-pop, and religious subjectivity.

\section{Literature review: key studies on Muslim K-pop fan subjectivity}

To date, studies specifically focusing on the religious subjectivity of the Muslim K-pop fans were still scarce. In this section I will discuss three most relevant key studies which have attempted to understand the ways Muslim K-pop fans negotiated their religious and fan identities. These three studies were chosen here because they provide valuable conceptual contributions to the available knowledge on K-pop and Muslim subjectivity, of which the current study is built on and seeks to extend.

The first is Yoon's (2019, p. 17) ethnographic studies on Indonesian K-pop fans in Jogjakarta, where she interviewed young fans who are both pious Muslims and zealous lovers of K-pop. Yoon argued that these fans were "emulating Korean pop culture but not to evade from social norms and religious doctrine" by, for example, imitating their idols' hairstyle underneath their hijab, wearing hot pants in their own bedroom, and applying Korean lip tint in the deep side of their lips. Yoon's analyses also drew attention to new masculine ideals and socio-spatial visions these fans adopted from K-pop as a form of resistance to the dominant gender and cultural norms, such as idealising hardworking and kind men, and wishing for clean and safe streets for women to roam around; which, most of the time, were unavailable in their everyday lives. However, Yoon did not intently delve into religious parts of the fans' subjectivity, but rather, the wider socio-cultural-transnational contestations, such as gender norms. The current study seeks to expand these findings. My analyses (in the Findings section below), for example, found that Yoon's participants only represents one or two out of several ways young Indonesian Muslims negotiate their religious and fan identities.

In contrast, Syed and Kwon's (2019) study among Malaysian Muslim university students who were exchange students in Korea focused more intently on the religious subjectivity (as well as the gendered and transnational aspects), such as wearing hijab and maintaining halal diet while living in Korea as a symbol of honour as a Muslim. However, Syed and Kwon did not specifically examine their identities as fans because the participants narrated more about their experience living in Korea rather than as a fan. For instance, their participants learned to put on Korean make up - and consider it a form of women empowerment in the public domain - since they arrived in Korea and "started to mix around" (Syed \& Kwon, 2019, p. 16), not because they were K-pop fans. Another example is their comments on the incident of a Korean singer hugging and kissing Malaysian Muslim girls in a concert (Ahmad \& Lee, 2016) which empathically positioned these fans as "a bunch of kids" (Syed \& Kwon, 2019, p. 11) who should not be publicly shamed for their mistakes; and simultaneously distanced themselves from these "childish" fans. The current study 
built on and complement these previous studies by focusing precisely and intently on the intersection of being a Muslim and a fan.

The third key study upon which the current article was built on and seeks to contribute is Oh's (2017) study on Muslim K-pop fans in Indonesia and Palestine. Comparing both countries and connecting Islam with state violence, Oh explored the possibilities that K-pop culture delivers "a new cultural message to the Muslim youths (predominantly female), who yearn for cultural liberation from oppressions of all kinds" (Oh, 2017, p. 234) including gender, religious, and state oppressions. While his Indonesian participants, to a degree, expressed this possibility, such as how K-pop inspired a more agentic version of womanhood, or how a Christian Chinese-descendant fan feared reactionary responses from hard-line Muslim groups or the government, Oh's analysis might be problematic on several grounds. Firstly, the undertones of Oh's article appear to equate Islam and Muslim-majority countries with female oppression ("all local cultures in the Islam countries [sic] seem to discriminate against women”, Oh, 2017, p. 235). Secondly, Oh imprecisely positioned Indonesia as a conservative "Islamic state", without considering the spectrum of progressive-conservative Islamic influences on Indonesian socio-cultural-politics - like the development of Islamic feminist movements (e.g., Robinson, 2006) - such as when he claimed: "While Islam has changed its faces over various historical periods in the two countries, what remained unchanged was women's status under Islam" (Oh, 2017, p. 248). Thirdly, drawing upon a single evidence of apprehension from a fan, Oh might have exaggerated the potential of state violence towards K-pop fans which, he acknowledged himself hitherto unproven ("There has not yet been any state violence reported on the Islamic women who consume Hallyu [K-pop wave] in large quantities in each country", Oh, 2017, p. 244). In fact, while taking her daughter to a K-pop concert, the president Jokowi called himself "a K-pop fan" when interviewed by a Korean media (Yolanda, 2016), which is not surprising considering the potential of the pop culture industry in the eyes of this economicgrowth-oriented president. Acknowledging that Oh's findings might have a degree of credibility albeit sometimes imprecise and one-sided, the current article seeks to offer a more nuanced analysis, namely, a range of possible discursively-constituted subject positions occupied by Indonesian Muslim K-pop fans; with an awareness of the complexities of contemporary Indonesia's political, religious, cultural, and discursive tensions.

\section{Methodology}

The current study drew upon two forms of qualitative data, namely existing literature and interview transcripts, to explore various ways of being an Indonesian Muslim K-pop fan. The literature here refers to both popular online sources such as news, websites, and blogs; and academic publications, including narratives quoted in them. For the popular source, the purpose was to explore various messages in online sources which are readily available for and easily accessed by young people. To this end, two search terms, namely "K-pop \& Islam" and "Hallyu \& Islam" were applied in Google Indonesia (google.co.id.) search engine on July 2020. The first 
five pages generated were saved and analysed as data; the exclusion criteria was academic sources and online shop advertisements. The final number of popular sources analysed was 41 . For the scholarly search, both search terms were applied in five scholarly search engines or databases, namely, Sage, Springer, Taylor and Francis, Wiley, and Google Scholar Indonesia. The inclusion criteria was original, empirical research that analysed data on experiences as or scandals involving Muslim K-pop fans published between 2010 and 2020; the exclusion criteria was student papers. The final number of scholarly sources included was 16 .

Interview participants were recruited by posting advertisement on student instant messaging groups in the researcher's university and the research assistant's social media accounts. The criteria were Indonesian Muslim, female, 16-24 years old, and self-identified as a K-pop fan for at least one year. Considering global K-pop fandom is overwhelmingly women, only female fans were recruited for this study; male fans might be an exceptionally unique niche. Participants who responded to the advertisement were given an information sheet and an opportunity to ask questions about the study. Upon completing the consent form (and parental consent for under 18 years), each participant was interviewed in a 1-h session of audio-taped, semi-structured, narrative interview. Additionally, brief correspondences (1-3 times) via instant messaging were conducted when necessary, such as to confirm or probe some answers during the interview. At the end of the interview, participants were asked whether they can forward the advertisement to other fans they know. The total number of participants is 26 . While their views on their own religiosity are varied from not very religious to relatively religious, all are affiliated with the dominant moderate groups, namely, NU or Muhammadiyah. The interview questions include their first engagement with K-pop, their activities as a fan, their religious background, their views on their own religiosity, and their views on faith and fandom. The interviews were conducted in the participants' first language, that is, Indonesian language. The interviewers were the researcher and the research assistant, who are native Indonesian speakers. All participant names in this article are pseudonyms. The data collected (popular and scholarly literature, and interview transcripts) were analysed using a thematic analysis technique (Braun \& Clarke, 2006), in which researchers familiarised themselves with the data, organised them, and then identified, specified, and reviewed themes emerging from the data.

\section{Findings}

The analyses revealed at least four subject positions which have been, or available to be, taken up by Indonesian Muslim fans in understanding and acting upon the interplay between their faith and K-pop fandom. These four ways of being can be grouped into two categories: those representing "tensions" and "no tensions" between their subjectivity as a fan and a Muslim. The "tension" category can be divided into two sub-categories or positions, namely, (1) complete opposition, and (2) partial opposition between Islam and K-pop. The "no tension" category also has two sub-categories, that is, (3) irrelevance and (4) the interlacing of the subjectivity as a Muslim and a fan. It is important to note that these positions might not be strictly separated, 
as some fans simultaneously occupied more than one subject position. The analyses were also cannot be separated from the contextuality of participants in this study, namely, Muslim fangirls living in Indonesia with its specific gender, religious, historical, and cultural contexts. These four positions will be discussed below.

\section{“Muslim fans must repent": Complete opposition between Islam and K-pop}

[The Korean Wave] offers something interesting, and refreshing like water, which actually draws Muslims into the fire [of hell] ... Muslim fans of K-pop [must] repent.

$\sim$ Fuadh Naim, a popular conservative preacher (Arbi, 2019: para. 6 and 8).

As illustrated in the quotation above, the first position considers that being a Muslim and a K-pop fan is completely opposing each other, and Muslim fans must choose one or the other. This position represents conservative Muslim groups' stance, who have made their views readily available and easily accessible in various Indonesian online platforms (Fealy, 2019). There are at least three arguments within this position. Firstly, it is forbidden to admire a non-Muslim celebrity. As articulated by one of the most popular conservative preachers, Ustad Abdul Somad (Hukum menggemari artis Korea 2017): "Koreans are infidels (kafir). Do not like infidels. Whoever [likes] infidels, he/she is a part of the infidels." Another online popular source entitled "Islamic Law on Liking K-Pop (Hukum Menyukai K-pop, n.d.), quoted scriptures and hadiths such as QS. Al Mujadilah: 22: "You will not find a people who believe in Allah and the Last Day having affection for those who oppose Allah and His Messenger" and "No one loves a people but one who will be gathered with them on the Day of Resurrection"; to demonstrate that Islam opposes K-pop fandom because of the religion of the Korean artists, and the consequence is to be gathered with them in hell. Correspondingly, a participant in this study (Jessi, 21 yo) succinctly summarised what she knows about Islamic teachings on K-pop: "K-pop fans are kafir". These exclusionary remarks position K-pop fans outside of the Islamic faith, which implies one of the most sinful things to do in Islam, namely, leaving the religion (murtad).

The second argument is that K-pop culture opposes various aspects of Islamic sexual morality, and therefore, is sinful. Discussions in blogs and forums on $\mathrm{K}$-pop and Islam often pointed out the relatively relaxed mingling and intimate relationships between unmarried men and women in K-pop music videos or dramas, which are against conservative Islamic norm of avoiding courtship or dating (e.g., Siro, n.d.). The frequently-cited scripture is "a man should never be alone with a woman, unless the woman is with her guardian" (e.g., Yulianto, 2017). Concerns around physical proximity between sexes which implies gestures of intimacy and sexual textures have also underpinned condemnations against veiled Malaysian Muslim fans being hugged and kissed on stage by a K-pop singer in a concert in 2015 (Ahmad \& Lee, 2016). Another problematic aspect of K-pop according to conservative Islamic sexual morality is that Korean artists, videos, and dramas display aurat, that is, parts of women's body that should be covered by a hijab. There was moral panic around concerns that young Muslim girls 
might imitate K-pop clothing. A participant in this study, Alina (20 yo), admitted that she did "want to imitate K-pop clothing" but, she "thanked God" she was "strong enough not to". Another example is an Indonesian petition signed more than 127,000 times in 2018 against an online marketplace advertisement featuring Korean girl band, Blackpink, wearing off-shoulder, short skirt dresses (Hentikan iklan Blackpink Shopee, n.d.). Maimon Herawati, the petition initiator, argued that the advertisement exposes aurat, is inappropriate for children, and displays seductive expressions and bodily movements. Here, K-pop is deemed representing sexual immorality from which young Muslim girls are positioned as needing protection.

Thirdly, indulging oneself in entertainment or sexual pleasure through pop culture is seen as hedonistic and against Islamic values of modesty. The K-pop industry has mastered the art of building emotional connections and maintaining fandom hitherto unequalled by any other modern popular culture (see Jung, 2011; Jung \& Shim, 2014). K-pop keeps fans hooked up through market-tested strategies such as - among others - intense social media engagement, constant updates, online forums, merchandises, fan fictions, and live apps peeking into the artists' everyday life. Thus, to be overly passionate and intensely involved in any nonIslamic activities, like being a K-pop fan, is deemed fundamentally problematic especially because K-pop represents "youth lifestyles full of worldly pleasures, and encouraging Muslim youth to follow such lifestyles" (Firsty, 2014). An Indonesian Islamic website featuring an article entitled "K-pop virus and the deconstruction of Islamic faith" (Saad, 2012) even labelled K-pop as a "latent threat for Muslims", "polluting Indonesia's famously polite culture", "eroding Islamic morality", "bourgeois", "hedonist", and "materialist".

This position of "complete opposition" has evidently been taken up by Muslim fans as documented in previous studies, and also by some participants in the current study. Adila (21 yo), a participant in this study, was aware that being a K-pop fan opposes her faith and she had to choose one over another. She comfortably chose K-pop because she considered herself as "not very religious anyway." In Sirry's (2020) study among radical-leaning groups in Indonesian universities, a participant reported how the Islamic group she joined condemned K-pop and it caused a religious moral dilemma for her as a K-pop fan. This "complete opposition" position constituted through conservative Islamic discourses was what precisely made her leave that radical-leaning group. Some of Yoon's (2019) participants also represented the taking up of this subject position which resulted in clandestine practices of emulating K-pop culture among Indonesian fans, such as enjoying K-pop in the secrecy of their bedroom, setting their hair like Korean stars underneath their hijab, and wearing hot pants only in their private space; because K-pop culture was understood as opposing the general rules of their faith. As a participant in our study noted (Mira, 21 yo, self-identifying as an ex-fan), "repentance - leaving K-pop fandom - is the only way out for Muslims." This "complete opposition" stance signifies, continues, and expands tensions between rising Islamic conservatism and popular culture in contemporary Indonesia (Harnish \& Rasmussen, 2011; Weintraub, 2011b). 


\section{Islamised K-pop and "K-popped" Islam: Partial opposition between Islam and K-pop}

As Allah said, "Oh mankind, we created you from a single (pair) of a male and female, and we made you into nations and tribes, that you may know each other (not that you may despise each other)." But in that purview, Islam limits this mixing by taking only the useful things from the culture and the things that match with Islam. You should reject what goes against Islam and its values. There are some sides of Hallyu that Islam forbids such as singing and dancing and the intense relationships between the two genders. (Maysa, Palestinian K-pop fan, a participant in Oh, 2017, p. 249)

In contrast with the "complete opposition" position, the second position - which still implies tensions between Islam and K-pop - considers only some parts of K-pop culture as opposing Islamic beliefs. Here, being a Muslim fan is possible or not fundamentally wrong, as long as the problematic parts are avoided. As illustrated by Oh's (2017) Palestinian participant above, Muslim fans can "filter out" aspects of K-pop which they considered religiously wrong, and take only the good things from K-pop. This is the most popular position among participants in the current study, which discursively challenges the conservatives' strict oppositional positioning of Islam and K-pop. In this section I further argue that, this partially opposing subject position has consequentially given rise to different forms of religio-cultural redefinition, including Islamised versions of K-pop culture, and "K-popped" versions of Islamic culture.

Corresponding to the three reasons about how K-pop is in opposition to Islam in the previous section, there have been ways to give meaning differently to Islam and K-pop which circumvented those three reasons, as demonstrated by fans and Muslim communities in previous studies and in popular media. Firstly, when admiring a non-Muslim is considered sinful, admiring Muslim K-pop stars may solve the problem. In Indonesia, there has been media coverage on Muslim Korean artists, such as Manny, a member of the Varsity K-pop boy band (Sadikin \& Suliastini, 2018), Daud Kim, a Korean Youtuber and singer (Garjito, 2020), and, most notably, Ayana Jihye Moon, a veiled Korean Internet celebrity (3 fakta Ayana Moon, 2020). Some of them are converts, and others were born Muslim. Unsurprisingly, these Muslim Korean celebrities are increasingly gaining a considerable number of followers in Indonesia (Marhendri, 2020).

Secondly, when K-pop culture is deemed morally wrong because it could encourage Muslim fangirls to expose their aurat, some Indonesian Muslim fans, such as in Novchi, Hanafi, and Arlizon's study (2018, p. 49), imitated K-pop fashion selectively in ways that do not expose aurat: "Muslim clothes ... are more polite. [We dressed] polite[ly], but similar [to Korean stars]. Just like that, not [copying] everything." These fans demonstrated that enjoying K-pop does not imply mindless imitations of K-pop culture, but they appropriated such foreign culture and aligned it with local religious values (Rosidi, 2016). This is similar to the Islamic take on Japanese pop culture of costume play (cosplay), namely, hijabi cosplay (Gittinger, 2018) in which Muslim fans dressed up as an anime 
character but were still covered by a veil. These Islamised versions of K-pop evidence and continue the history of hybrid fuse between Islam and popular culture in the Malay world (Harnish \& Rasmussen, 2011). Simultaneously, fangirls taking up this position disrupted the hegemonic ideas about young Muslim girls who need protection from external influences corrupting their sexual morality by demonstrating that they are agentic, understand religio-cultural boundaries, and able to make reasonable decisions for themselves.

Thirdly, when overly indulging oneself in worldly entertainment is considered sinful, some Indonesian fans in the current study moderated and controlled the indulgence, arguing that being a fan is unproblematic as long as "religious obligations (especially praying five times a day) are not abandoned" (Alia, 21 yo; Peep, 21 yo; Putri 25 yo), and thus refusing K-pop being framed as inevitable al-malāhi . Other limits participants set between sinful or not include "being majnun or stupid or irrational" (Siti, 21 yo) and "worshipping (K-pop) idol" (Agnes, 21 yo; Aisyah, 22 yo) or "making K-pop idol god" (Cheeze, 23 yo; Peep, 21 yo) which evokes the notion of shirk. In taking up subject positions where only some aspects of K-pop or some forms of engagement with K-pop are considered opposing Islamic beliefs, these fans have navigated ways to be both a good Muslim and a fan; and simultaneously, created unique versions of Islamic K-pop fandom. In so doing, these "moderate" fan subjectivity discursively contests strict conservative teachings on Islam and $\mathrm{K}$-pop widely available in the Indonesian popular online sources.

Further, it is not only the K-pop industry that sought to capitalise on the growing Muslim fandom, but also conservative Islamic groups in Indonesia. For instance, the organiser of Hijrah Fest - a modern take on Islamic rally - admittedly took K-poplike strategies in the design of their events. Accommodating the new Indonesian Muslim middle-class, their annual events were held in the luxurious Jakarta Convention Center, featuring born-again (hijrah) celebrities and business people. They charged a daily entrance ticket of 95,000 rupiah which steered clear the event from lower class visitors. One of the event's organisers was interviewed by the media and he said: "I was a K-pop fan. But after I hijrah, I want to take advantage of K-pop popularity for dakwah, for K-pop fans in Indonesia" (Aurelia, 2019: para. 32). The K-pop-like strategies identified by this media report include inviting preachers with a large number of social media followers, providing meet-and-greet-like sessions, and selling halal products in a pop-up market featuring popular vendors and startups akin to anime conventions. Ayana Jihye Moon, for example, was invited as one of the speakers. With more than 3 million Instagram followers, she was welcomed by a large number of visitors who were enthusiastically lined up to shake her hand and take selfies - a scene which was reminiscent of K-pop fandom. Beside Hijrah Fest, another example of adopting popular culture for Islamic dakwah can be found in the Indonesian preacher who popularised himself as Ustad Naruto (Ada Ustaz Naruto, 2018). Capitalising on Japanese pop culture fandom, he wore the costume of Naruto, a popular anime character, when preaching to expand his appeal to young J-pop fans. By selectively filtering out things that are opposing Islamic beliefs and taking only the "good" things from K-pop for Islamic endeavours, this position of partial opposition provides Muslims with ways to enjoy the pleasure of fandom either through an Islamised version of K-pop, or "K-popped" versions of Islamic faith. 


\section{"It has nothing to do with my religious life": K-pop as irrelevant with one's faith}

I think there is only difference in culture between Indonesia and Korea...

but I have never seen Korean stuff from religious perspective."

$\sim$ An Indonesian Muslim K-pop fan, cited in Yoon (2019)

While the first two subject positions discussed in this article were predicated upon a belief that Islam and K-pop culture are in tension, the final two subject positions focus on Muslim fan subjectivity which considers there is no tension between one's identity as a Muslim and being a K-pop fan. This section will discuss the first no-tension subject position, that is, Muslim fans who see their faith as irrelevant with their practices and subjectivity as a fan. These fans did not think about K-pop from a religious perspective, and did not feel that there were tensions between the two. Although quite limited, there were glimpses of such subject positions among participants in the current study, as well as in previous studies.

One initial evidence can be seen in Hong and Lee's (2017) quantitative study on patterns of K-pop consumption among Buddhist, Muslim, and Catholic fans in Vietnam, Malaysia, Costa Rica, Peru, and Chile. Published as a conference paper, the methodological and theoretical robustness of their study might not be exceptionally convincing. Nevertheless, their study evidenced there was at least an indication that some fans have responded "it has nothing to do with religion" when asked directly about the impact of K-pop on their religious life; in their case, the majority of respondents from three religions chose that answer. Based on this data, Hong and Lee (2017, p. 139) concluded that "Korean culture and content does not help, nor disturb the religious life." However, this quantitative data was unable to explain further how fans articulated such irrelevance, particularly Muslim fans, amidst the apparent tensions between Islam and K-pop as discussed in previous sections.

Qualitative data from the current study might complement Hong and Lee's (2017) statistics. One participant, Anna (21 yo), is a university student who diligently observes Islamic teachings and rituals. She considered herself as coming from "a conservative family in a particularly conservative region in Indonesia". She was able to explain why many Muslims - including her father - frown upon listening to pop music, attending concerts, going to the cinema, and even watching TV; because none of these contribute to their raison d'être, that is, spiritual growth. It was not until I specifically asked "what about your opinion", that she stopped repeatedly using the phrase "in Islam, ...", and started expressing her own views. She explained:

In my view, I know they [Korean artists] are not Muslims, but I don't focus on that part. I like Seventeen, for example, I don't see their religion, or values or influence they bring. Those do not influence me at all. I am interested in their dance, their choreo[graphy], that's all. Watching their concert relieves my stress, it is really just for entertainment.

In this narrative, Anna does not consider religion as a relevant issue in being a fan. For Anna, consuming K-pop as entertainment has nothing to do with the Korean artists' or her religion. Since Korean celebrities she liked did not promote their religions, and she did "not focus on that part", she did not find their religions or values influencing 
her. This notion of "just for entertainment" is also precisely the discourse drawn upon by Yoon's (2019) Muslim participants in explaining the irrelevance of their Islamic faith and K-pop fandom (“... anyway it's for entertainment ...”, Yoon, 2019, p. 11). Other expressions relating to this position from participants in the current study include "no need to mix hobby and religion" (Cheeze, 23 yo) and "religion and hobby are different, they have their own place" (Fira, 21 yo). Here, religion and entertainment/hobby were considered two different domains of life, which did not necessarily influence each other. In this way, these participants demonstrated the ways in which Muslim fans may position their Islamic faith as having nothing to do with K-pop fandom.

It is noteworthy that, Anna (21 yo) and other participants displayed a repeated pattern of explaining Islamic teachings on K-pop, then followed by phrases "but for me" (Jessi, 21 yo) or "according to me" (Ceri, 20 yo) to express their own interpretations. Considering the generally authoritative manners of religious teaching in Indonesia, such gesture represents a subversive exercise of agency where young Muslim girls expressed disagreement with religious authority and claimed their own voice through their engagement with K-pop. Ceri's (20 yo) narrative best demonstrates such exercise of agency:

According to me, music is the least harmful thing in the world. As long as we don't use it for something evil, I - as a Muslim - have no problem with K-pop music. If someone says it sinful, I think it is a matter between me and Allah. I don't think humans can easily interpret Allah's message. We're just humans after all.

However, there might be some limitations within this analysis. It can be argued that ideological shifts might have happened discursively or even subconsciously. Since Anna became a K-pop fan, for example, she prefers soft masculinity, "hygienic, and boyfriendable boys", which was different from the dominant masculine norms in Indonesia (Yoon, 2019). Islam, as the main source of her life values, might have been partially replaced by K-pop culture without her being aware of it. Ostensibly two disconnected domains, previous studies have shown how K-pop as an entertainment could became a channel for feminist discourses contesting one's conservative religious beliefs, such as how Muslim participants' in Syed and Kwon's (2019) study encouraged women to speak up. Similarly, after watching Korean dramas and music videos, fans in Yoon's (2019) study wished for safe streets for women to roam; pushing the boundary of traditionally domesticated roles of women. Instead of Islamic feminism, K-pop culture became the source of such discursive contestations. While Hong and Lee's (2017) claim that K-pop does not disturb nor help fans' religious life - therefore, irrelevant to their faith - might have a degree of credibility, there is also a possibility that K-pop discursively contesting religion as the source of life values, socio-spatial visions, and criteria of an ideal boyfriend.

\section{"Assalamualaikum, annyeonghaseyo": The interlacing of Islam and K-pop in the constitution of Muslim fans' subjectivity}

I found that Korean culture as reflected in the Korean television dramas is Islamic. 
Bunga, an Indonesian Muslim K-pop fan (cited in Rosidi, 2016, p. 17)

The final subject position I discuss here under the no tension category is the interlacing of one's identity as a fan and as a Muslim. While acknowledging differences and opposing aspects, some fans demonstrated that they emphasised more on the similarities and cross-connections between K-pop and Islam. Struggling to reconcile the tensions, therefore, was not a major part in the constitution of their subjectivity as a Muslim fan. Quite the opposite, these fans spoke about ways in which one's identity as a fan made them a better Muslim, and how being a Muslim enhanced one's experience as a fan. As the epigraph above showed, there have been studies identifying and demonstrating such subject position, as well as participants in the current study, albeit quite rare.

One participant in the current study representing this position is Lila, a 16-yearold high school student who identifies herself as a K-pop fan. As a daughter of a progressive Muslim preacher, Islam has been an important context of her life; she went to Islamic schools, she learned to read the Quran since kindergarten, and she believes Islam is the "guide of her life". Like Anna, Lila is aware of the tensions between K-pop culture and Islamic teachings, but, personally, she did not attribute great importance to such opposing aspects. Unlike Anna, Lila considered her "progressive" father as relatively supportive of her interests in K-pop. Throughout the interview she frequently expressed cross-references between Islam and K-pop, demonstrating how K-pop culture and religion were intertwined in her sense of self. For instance, Lila called the early phase of her being a fan (when K-pop was her only reason to live everyday, when she abandoned her homework and grades, when she was aggresive towards anyone criticising K-pop) as "the age of Jahiliyah" (i.e., the word Muslims use to refer to the age of ignorance in pre-Islamic Arabia). Lila also referred to a saying from the Hadith (a major source of Islamic teachings apart from the Quran) "cleanlines is next to godliness" when she passionately argued that it is good for men to take good care of his body and hygiene, like male Korean artists she liked. Currently considering herself a more mature fan, she now emphasised the importance of moderation in being a fan ("it's okay to be a fan, just don't [be] too much"), which is reminiscent of the moderate Islamic tradition her family is affiliated with (NU), as well as in the tone of her talk about religious morality ("who are we to accuse someone as sinful", "as long as we don't hurt others"). As these narratives show, Lila's ways of being a fan and a Muslim were closely interlaced, both affecting each other, both became a lens to give meaning to the way the other was experienced.

There were at least five points of cross-connections between Islam and K-pop that have been identified by fans taking up this subject position, including fans in the current and previous studies. The first is cleanliness, as mentioned by Lila above. Muslim fans in previous studies also highlighted cleanliness they saw in K-pop culture as an Islamic aspiration. In addition to Lila who talked about men's personal cleanliness and care, Muslim participants in Rosidi et al. (2019, p. 222) study commented on public cleanliness: "In Korean dramas, I saw the neighbourhoods are clean, no garbage ... the streets are nice, and no garbage on the streets. Indonesia has to be like that too!" Rosidi et al. (2019) then concluded that Korean dramas contributed to 
the enactment of Islamic values of cleanliness to Indonesian Muslim fans. Similarly, Yoon (2019) who is a Korean researcher, was surprised how much her Indonesian Muslim participants talked about streets and garbage when they compared Korea and Indonesia.

Secondly, another Islamic value highlighted by Muslim K-pop fans in previous studies is being hardworking. Indonesian participants in Oh's (2017), Rosidi et al.'s (2019), and Yoon's (2019) study saw in Korean dramas and among K-pop artists that the protagonists worked really hard to find a job, to study for examinations, or to rise as a K-pop star. Rosidi et al. (2019) connected these K-pop representations of hard work with a verse from the Quran (At Taubah 9, p. 105): "Work; so Allah will see your work and (so will) His Apostle and the believers", and further claimed that K-pop culture "can teach Islamic values for young Indonesian Muslims" (Rosidi et al., 2019, p. 223).

Thirdly, K-pop's representations of family values have also been pointed out by Muslim fans as enhancing their religious beliefs and practices. These fans identified how Korean dramas and music videos were imbued with family values, such as "showing respect to elders" (Syed \& Kwon, 2019, p. 16), "honoring one's parents" (Oh, 2017, p. 249), "family ties are strong" (Oh, 2017, p. 250), and "youth respecting their father or mother" (Rosidi et al., 2019, p. 221). For some fans, these portrayal of family values were reminiscent of the Islamic concept of silat al-rahim, that is, the Islamic moral value of nurturing relationship between family members and in the society, including respecting the elders (ElDakhakhny, 2017).

Fourthly, some participants in the current study (Agnes, 21 yo; Peep, 21 yo; Siti, 21 yo) described their involvements in K-pop fan groups as enhancing their religiosity because they engaged in sadaqah or charity such as making a group donation for those in need under the name of their favourite Korean artist/band. As Siti (21 yo) narrated: "Helping other is a sunnah for Muslims, and that's what we did to celebrate our K-pop star's birthday."

The fifth is religion and K-pop as sources of comfort and strength that go hand in hand. As Agnes (21 yo) described: "I was once on my lowest point. The first thing I did was salat and tell everything I felt to Allah. Then I listened to relatable K-pop songs ... so I'm still alive until now". In the increasingly neoliberalised Indonesia, both market and parental pressures for youth to study hard and work hard often result in poor mental health (Wijaya Mulya et al., 2021a). For these participants, K-pop and Islam became ways of "healing from everyday life", sources of "comfort words" and "sense of being loved" (Fira, 21 yo) - a spiritual refuge from harsh capitalist competitive worlds, an empowering energy to survive depressing and suicidal thoughts ("so I'm still alive until now", Agnes, 21 yo).

Further, a participant in this research, Aisyah (22 yo), took K-pop further into critical reflections on the nature of religion, God, and life: "I sometimes immersed in K-pop too far. Once realising it I immediately istighfar (seeking Allah's forgiveness), but not because I fear Allah is jealous, rather, I need to be balanced (tawazun). Allah doesn't need me to worship that much anyway. Life isn't black and white, it's all about balance." Through Aisyah's engagement with K-pop, she demonstrates a spiritual understanding of Islam; one that is not doctrinal and authoritative, nor focusing on obedience, morality, and piety as commonly advocated by the 
conservatives (Wijaya Mulya et al., 2021b). The constitution of her subjectivity as a Muslim K-pop fan here evidenced a resistance against the widespread conservative Islamic discourses in contemporary Indonesia. A spiritual approach to Islam and K-pop can also be found in ElDakhakhny's (2017) autobiographical research on being a Muslim K-pop fan in Egypt. As she started to learn some Korean vocabularies, she was fascinated by the meaning of Korean greeting annyeonghaseyo which translates as "Have you been well/at peace?". She could not help but seeing the meaning of the greeting as strikingly similar to Arabic greeting, assalamuaikum, which is commonly used among Muslim communities all over the world, including in Indonesia. This Arabic greeting means peace be upon you, and God's mercy and blessings. As in ElDakhakhny's experience, the centrality of the word "peace" in these greetings may serve as a spiritual linkage for Muslim K-pop fans, namely, a reminder of the common humanity across religions, traditions, and (pop) cultures. At this spiritual level of understanding social realities, identities as a K-pop fan and a Muslim can be entwined in a harmonious co-existence.

\section{Conclusion}

This article has discussed various ways Muslim K-pop fans negotiated the interplay between their religious and fan subjectivity. The analysis revealed there are at least four subject positions (available to be) taken up by Muslim fans; from complete opposition, partial opposition, irrelevance, to the interlacing of identities as a Muslim and a fan. These findings are not intended to be comprehensive nor exhaustive, but to modestly illustrate various possibilities of being and becoming a Muslim K-pop fan. While located in a specific geographical situation (i.e., Indonesia), some of the data analysed also included relevant narratives from other Muslim communities, so that findings in this study might also resonate with Muslims in other places - although carefulness is necessary in terms of the transferability of the study. This article contributes to the existing knowledge in the field of Islam and popular culture by offering an initial, nuanced discussion on various possible forms of Muslim K-pop fans' subjectivity.

The implications of the current research are as follows. Firstly, for Muslim K-pop fans, this article offers discursive resources on various possibilities of becoming a fan. For fans who felt lacking in agency, drawing upon alternative discourses and giving meaning differently to their sense of self can be an agentic act of ideological resistance - since the personal is political - and simultaneously, can be therapeutically liberating. Secondly, for the K-pop industry, a better understanding of Muslim fans' religious subjectivities may inspire marketing strategies which are more diverse and more accommodative of the fans' contextual situations, for example, a hijab-friendly K-pop fashion niche. Thirdly, for future studies, the current article identified some vague glimpses of various other domains of discursive contestation when K-pop cultures encountered local Muslim fandom, such as gender, sexuality, socio-spatial justice, and neoliberal ethos (e.g., hardworking individuals who are responsibilised for their own success). Future studies may explore these 
contestations to further examine the complexities of the constitution of Muslim K-pop fans' subjectivity.

Funding No funding was received for conducting this study.

Data availability Qualitative data in this study are kept confidential.

Code availability Not applicable.

\section{Declarations}

Conflict of interest The author has no conflicts of interest to declare that are relevant to the content of this article.

\section{References}

3 fakta Ayana Moon, rumor mantan idol K-pop hingga ditolak keluarga. [3 facts about Ayana Moon, from rumored as an ex K-pop idol to family rejection]. (2020, May 12). Insertlive. https://www.insertlive. com/hot-gossip/20200512075434-7-139772/3-fakta-ayana-moon-rumor-mantan-idol-k-pop-hinggaditolak-keluarga

Ada ustaz Naruto di pengajian ini, dresscode nya anime dan superhero. [Naruto preacher in this Islamic gathering, the dresscode was anime and superhero]. (2018, October 22). Batok.co. https://www. batok.co/2018/10/22/ada-ustaz-naruto-di-pengajian-ini-dresscode-nya-anime-dan-superhero/

Ahmad, W. A., \& Lee, A. Y. B. (2016, December 15). Hugging and hallyu: Examining representations of moral panic and the Korean wave in the Malaysian media. Social Sciences Postgraduate International Seminar, Universiti Sains Malaysia, Penang, Malaysia. http://www.soc.usm.my/images/pdf/ Proceedings-for-Social-Sciences-Postgraduate-International-Seminar-SSPIS-2016.pdf

Arbi, I. A. (2019, February 27). K-pop promotes LGBT lifestyles, free sex, famous preacher tells Muslim fans. The Jakarta Post. https://www.thejakartapost.com/news/2019/02/27/k-pop-promotes-lgbt-lifes tyles-free-sex-famous-preacher-tells-muslim-fans.html

Aurelia, J. (2019, May 27). Merebut ambisi hijrah lewat K-pop hingga hapus tato. Tirto.id. https://tirto.id/ merebut-ambisi-hijrah-lewat-k-pop-hingga-hapus-tato-d5lb

Barendregt, B. (2012). Sonic discourses on Muslim Malay modernity: The Arqam sound. Contemporary Islam, 6(3), 315-340. https://doi.org/10.1007/s11562-012-0221-z

Braun, V., \& Clarke, V. (2006). Using thematic analysis in psychology. Qualitative Research in Psychology, 3(2), 77-101. https://doi.org/10.1191/1478088706qp063oa

Bruner, R. (2020). BTS's parent company is going public: Here's how the music industry could replicate its massive success. Time. https://time.com/5899791/bts-bighit-ipo/

BTS' new album 'BE' tops iTunes charts in 90 countries. (2020, November 22). The Korea Times. https:// www.koreatimes.co.kr/www/art/2020/11/732_299666.html

ElDakhakhny, D. M. (2017). The yummy side of hallyu: A critical autoethnography. Plaridel, 14(2), 33-52.

Fealy, G. (2019). Reformasi and the decline of liberal Islam. In T. Dibley, M. Ford, \& Y. L. M. Sastramidjaja (Eds.), Activists in transition: Progressive politics in democratic Indonesia (pp. 117-134). Cornell University Press.

Firsty, A. F. I. (2014, January 31). Islam populer: Islam dan budaya K-pop di Indonesia [Popular Islam: Islam and K-pop culture in Indonesia]. Islam dan Budaya Lokal [Islam and Local Culture]. http:// muslimlokal.blogspot.com/2014/01/islam-populer-islam-dan-budaya-kpop-di.html

Fiscella, A. T. (2012). From Muslim punks to taqwacore: An incomplete history of punk Islam. Contemporary Islam, 6(3), 255-281. https://doi.org/10.1007/s11562-012-0225-8

Garjito, D. (2020, August 27). Profil Daud Kim, penyanyi asal Korea yang masuk Islam [The profile of Daud Kim, a Korean singer converted to Islam]. Suara. https://www.suara.com/entertainment/2020/ 08/27/112426/profil-daud-kim-penyanyi-asal-korea-yang-masuk-islam?page=all 
Gittinger, J. (2018). Hijabi cosplay: Performances of culture, religion, and fandom. Journal of Religion and Popular Culture, 30(3), 87-105. https://doi.org/10.3138/jrpc.2016-0005.r1

Hamamsy, W. E., \& Soliman, M. (Eds.). (2013). Popular culture in the Middle East and North Africa: A postcolonial outlook. Routledge.

Harnish, D. D., \& Rasmussen, A. K. (Eds.). (2011). Divine inspiration: Music and Islam in Indonesia. Oxford University Press.

Hebdige, D. (1979). Subculture: The meaning of style. Methuen.

Hentikan iklan Blackpink Shopee [Stop Shopee Blackpink advertisement]. (n.d.). Change.org. https:// www.change.org/p/komisi-penyiaran-indonesia-hentikan-iklan-blackpink-shopee. Accessed 7 Sept 2020.

Hilton, T. (2020, September 22). BTS, EXO, Super Junior: Why is K-pop so popular on Twitter in Saudi Arabia? Al Arabiya. https://english.alarabiya.net/en/features/2020/09/22/BTS-EXO-Super-JuniorWhy-is-K-pop-so-popular-on-Twitter-in-Saudi-Arabia-

Hong, M., \& Lee, H. (2017). Hallyu (Korean culture wave) trends in social and religious district. Paper presented at the Global Fashion Management Conference, Vienna. http://db.koreascholar.com/artic le. $\operatorname{aspx}$ ? code $=325241$

Hukum menggemari artis Korea [The law on liking Korean celebrities]. (2017). https://www.youtube. com/watch?v=x_qUQUzPYAo. Accessed 7 Sept 2020.

Hukum menyukai K-pop [The law on liking K-pop]. (n.d.). Dalam Islam. https://dalamislam.com/hukumislam/hukum-menyukai-kpop-dalam-islam. Accessed 7 Sept 2020.

Irama, R. (2011). Music as a medium for communication, unity, education, and dakwah. In A. N. Weintraub (Ed.), Islam and popular culture in Indonesia and Malaysia (pp. 185-192). Routledge.

Jeong, J.-S., Lee, S.-H., \& Lee, S.-G. (2017). When Indonesians routinely consume Korean pop culture: Revisiting Jakartan fans of the Korean drama Dae Jang Geum. International Journal of Communication, 11, 2288-2307.

Jung, S. (2011). K-pop, Indonesian fandom, and social media. Transformative Works and Cultures. https://doi.org/10.3983/twc.2011.0289

Jung, S., \& Shim, D. (2014). Social distribution: K-pop fan practices in Indonesia and the 'Gangnam style’ phenomenon. International Journal of Cultural Studies, 17(5), 485-501. https://doi.org/10. $1177 / 1367877913505173$

Kartomi, M. (2011). "Art with a Muslim theme" and "art with a Muslim flavor" among women in West Aceh. In D. D. Harnish \& A. K. Rasmussen (Eds.), Divine inspiration: Music and Islam in Indonesia (pp. 269-296). Oxford University Press.

LeVine, M. (2008). Heavy metal Muslims: The rise of a post-Islamist public sphere. Contemporary Islam, 2(3), 229-249. https://doi.org/10.1007/s11562-008-0063-X

Malik, S. I. (2019). The Korean wave (hallyu) and its cultural translation by fans in Qatar. International Journal of Communication, 13, 5734-5751.

Marhendri, D. (2020, May 7). Selain Ayana Moon, 5 seleb Korea Selatan ini juga pilih jadi mualaf [Beside Ayana Moon, these 5 Korean celebrities also chose to convert]. Merdeka. https://www. merdeka.com/jateng/selain-ayana-moon-5-selebgram-korea-selatan-ini-juga-pilih-jadi-mualaf.html

Masood, A., \& Rahim, A. A. (2020). Synergising hallyu and halal economy for wealth creation. Geografia Malaysian Journal of Society and Space, 16(1), 24-35. https://doi.org/10.17576/geo-2020-1601-03

Nieuwkerk, K. van, LeVine, M., \& Stokes, M. (Eds.). (2016). Islam and popular culture. University of Texas Press.

Novchi, R. W., Hanafi, K., \& Arlizon, R. (2018). The hallyu in Pekanbaru: An ethnographic study on Indonesian Kpopers parasociality. In Proceedings of Communication, Economic, Education, Law, Social Humanities, Science and Technology Conference, Riau, September 2018. Riau, Indonesia: Universitas Muhammadiyah Riau.

Oh, I. (2017). Islam and local culture: The peril of state violence and hallyu fandom in Indonesia (with reference to Palestine). Kritika Kultura, 29, 232-257.

Otterbeck, J., \& Ackfeldt, A. (2012). Music and Islam. Contemporary Islam, 6(3), 227-233. https://doi. org/10.1007/s11562-012-0220-0

Robinson, K. (2006). Islamic influences on Indonesian feminism. Social Analysis: The International Journal of Social and Cultural Practice, 50(1), 171-177.

Rosidi, I. (2016). Being active consumers: Indonesian Muslim youth engaging with Korean television dramas. Working Paper 23, Institute of Asian Studies, Universiti Brunei Darussalam. https://ias.ubd. edu.bn/wp-content/uploads/2018/09/working_paper_series_23.pdf 
Rosidi, I., Masduki, M., \& Triantoro, D. A. (2019). Nilai-nilai Islam dalam drama Korea perspektif anak muda Muslim Pekanbaru [Islamic values in Korean dramas from young Muslim's perspective in Pekanbaru]. Jurnal Dakwah Risalah, 30(2), 215-226. https://doi.org/10.24014/jdr.v30i2.8492

Saad, M. (2012, April 5). Virus K-pop dan dekonstruksi aqidah [K-pop virus and the deconstruction of Islamic faith]. Hidayatullah. https://www.hidayatullah.com/artikel/tsaqafah/read/2012/04/05/2325/ virus-k-pop-dan-dekonstruksi-aqidah.html

Sadikin, R. A., \& Suliastini, R. (2018, May 17). Yuk kenalan dengan Manny, idol K-pop pertama yang beragama Islam [Let's getting to know Manny, the first Muslim K-pop idol]. Matamata. https:// www.matamata.com/kpop/2018/05/17/151736/yuk-kenalan-dengan-manny-idol-kpop-pertamayang-beragama-islam

Siro. (n.d.). Pandangan Islam tentang mengidolakan artis Korea [Islamic view on idolising Korean celebrities]. Media Iman. http://sisirorotelu.blogspot.com/2016/12/pandangan-islam-tentang-mengidolak an.html. Accessed 7 Sept 2020.

Sirry, M. (2020). Muslim student radicalism and self-deradicalization in Indonesia. Islam and ChristianMuslim Relations, 31(2), 241-260. https://doi.org/10.1080/09596410.2020.1770665

Storey, J. (1999). Cultural consumption and everyday life. Edward Arnold.

Sumarsam. (2011). Past and present issues of Islam within the Central Javanese gamelan and wayang kulit. In D. D. Harnish \& A. K. Rasmussen (Eds.), Divine inspiration: Music and Islam in Indonesia (pp. 45-79). Oxford University Press.

Syed, M. A. M., \& Kwon, S.-H. (2019). Hallyu and strategic interpretation of Malaysian modernity among young Malay women. Asian Women, 35(3), 1-24. https://doi.org/10.14431/aw.2019.09. 35.3.1

Turner, G. (2003). British cultural studies: An introduction (3rd ed.). Routledge.

Undang-Undang Republik Indonesia Nomor 44 Tahun 2008 tentang Pornografi (Republic of Indonesia Law no 44 year 2008 about pornography). (2008).

Wallach, J. (2008). Modern noise, fluid genres: Popular music in Indonesia, 1997-2001. The University of Wisconsin Press.

Weintraub, A. N. (ed.). (2011a). Islam and popular culture in Indonesia and Malaysia. Routledge.

Weintraub, A. N. (2011b). Morality and its (dis)contents: Dangdut and Islam in Indonesia. In D. D. Harnish \& A. K. Rasmussen (Eds.), Divine inspiration: Music and Islam in Indonesia (pp. 318-336). Oxford University Press.

Wijaya Mulya, T., Salvi, F., Gorczynski, P., \& Wells-Brown, T. (2021a). The State and my happiness: Youth mental health, citizenship education, and discursive contestations in contemporary Indonesia. Children \& Society. https://doi.org/10.1111/chso.12481

Wijaya Mulya, T., Aditomo, A., \& Suryani, A. (2021b). On being a religiously tolerant Muslim: Discursive contestations among pre-service teachers in contemporary Indonesia. British Journal of Religious Education. https://doi.org/10.1080/01416200.2021.1917338

Yolanda, F. (2016, May 24). Daebak! Presiden Jokowi juga suka K-pop [Awesome! The President Jokowi also likes K-pop]. Ini K-pop. https://inikpop.com/daebak-presiden-jokowi-suka-k-pop/

Yoon, S. (2019). K-Pop fandom in veil: Religious reception and adaptation to popular culture. Journal of Indonesian Islam, 13(1), 1-20. https://doi.org/10.15642/JIIS.2019.13.1.1-20

Yulianto, A. (2017, October 13). Bolehkah berpacaran dalam Islam? [Is it permitted to date in Islam?]. Republika. https://republika.co.id/berita/oxpvku396/bolehkan-berpacaran-dalam-islam

Publisher's note Springer Nature remains neutral with regard to jurisdictional claims in published maps and institutional affiliations. 